\title{
Analisis durasi pertandingan bolavoli pada Proliga 2019 ditinjau dari sistem energi
}

\author{
Tirto Apriyanto*, Ika Novitaria Marani, Tiara Putri Banyunimas \\ Program Studi Pendidikan Kepelatihan Olahraga, Program Sarjana, Universitas Negeri Jakarta. \\ Jalan Pemuda No. 10, Rawamangun, Jakarta 13220, Indonesia. \\ * Corresponding Author. E-mail: ika.novitaria@unj.ac.id
}

Received: July 6, 2020 ; Revised: October 26, 2020 ; Accepted: July 24, 2020

\begin{abstract}
Abstrak: Penelitian ini mempunyai tujuan untuk mengetahui: 1. Durasi set pada tim bola voli Proliga tahun 2019 dan 2. Durasi pertandingan pada tim bola voli Proliga tahun 2019. Metode penelitian dalam penelitian ini adalah penelitian deskriptif menggunakan teknik survei. Pengambilan data dilakukan di Kantor PB. PBVSI Jakarta. Populasi penelitian adalah semua tim Proliga 2019. Sampel yang diambil sebanyak 9 tim yang terdiri dari 5 tim putera dan 4 tim puteri menggunakan teknik purposive sampling. Instrumen penelitian yang digunakan yaitu form. Data diperoleh dari scoresheet hasil pertandingan final four Proliga 2019. Teknik analisis data yang digunakan adalah teknik analisis statistik deskriptif. Hasil penelitian ini adalah: 1. Durasi pertandingan pada pertandingan final four Proliga 2019 yang paling cepat adalah 70 menit dan durasi pertandingan terlama adalah 151 menit. 2. Durasi set pada pertandingan final four Proliga 2019 yang paling cepat adalah 20 menit dan terjadi di durasi set 1. Sedangkan durasi set yang terlama adalah 41 menit dan terjadi di durasi set 3. Sehingga disarankan kepada para pelatih untuk selalu memiliki catatan terhadap spesifikasi permainan terutama durasi set dan durasi pertandingan dimanapun timnya bertanding.
\end{abstract}

Kata Kunci: Analisis Permainan Bola Voli, Durasi Set, Durasi Pertandingan.

\section{The analysis of volleyball match duration analysis in Proliga 2019 based on the energy system}

\begin{abstract}
This study aimed to determined: 1. The duration of the set on the PROLIGA volleyball team in 2019 and 2. The duration of the match on the PROLIGA volleyball team in 2019. The research method used in this research is descriptive research using survey techniques. Data were collected at the office of PP. PBVSI Jakarta. The study population was all 2019 Proliga teams. Samples were taken as many as 9 teams consisting of 5 men's teams and 4 women's teams using a purposive sampling technique. The research instrument used was a form. The data of which was obtained from the scoresheet of the 2019 Final Four Proliga match results. The data analysis technique used was descriptive statistical analysis techniques. The results of this study are 1. The fastest match duration in the 2019 Proliga Four Final is 70 minutes, and the longest match duration time is 151 minutes. 2.The set duration in the 2019 Proliga final four matches the fastest is 20 minutes and occurs in the duration set 1. While the longest set duration time is 41 minutes and occurs in the set duration 3. So it is advisable for the coaches to always have notes on the specifications of the game especially the set duration and match duration wherever the team is playing.
\end{abstract}

Keywords: Analysis of volleyball game, duration of set, duration of match.

How to Cite: Apriyanto, T., Marani, I. N, \& Banyunimas, T.P. (2021). Analisis durasi pertandingan bolavoli pada Proliga 2019 ditinjau dari sistem energi. Jurnal Keolahragaan, 9(1), 86-99. doi: https://doi.org/10.21831/jk.v9i1.33784

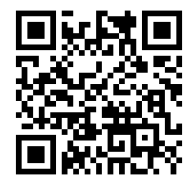

\section{PENDAHULUAN}

Prestasi bola voli Indonesia masih tertinggal terutama pada tingkat Asia. Namun di tingkat Asia Tenggara, bola voli Indonesia mulai bangkit untuk mengejar ketinggalan prestasi khususnya di kategori putra. Hal ini dapat dilihat pada kejuaraan SEA Games terakhir tahun 2019, Indonesia berhasil mendapatkan medali emas untuk bola voli putra. Perolehan medali ini mengakhiri paceklik 
prestasi timnas bola voli indoor Indonesia setelah terakhir kali timnas bola voli indoor Indonesia mendapatkan medali emas di SEA Games 2009 di Laos. Selama rentangan waktu penyelenggaran SEA Games, timnas bola voli putra selalu kalah pada partai final oleh tim yang sama yaitu timnas bola voli putra Thailand.

Prestasi timnas bola voli indoor putra tidak diikuti dengan prestasi timnas bola voli indoor putri. Hal ini dilihat pada saat SEA Games 2019, timnas bola voli indoor putri Indonesia hanya mampu mendapatkan medali perunggu. Sehingga hingga saat ini, prestasi timnas bola voli indoor putri telah menorehkan prestasi dengan mengoleksi 1 medali emas, 7 perak, dan 9 perunggu di ajang SEA Games sejak tahun 1977 hingga 2017 (Nindy, 2017). Berdasarkan gambaran prestasi tersebut, maka perlu mendapatkan perhatian dalam hal pembinaan dan perencaan program latihan sehingga prestasi yang ditargetkan dapat tercapai. Oleh karena itu, PP. PBVSI harus melakukan evaluasi tentang faktor-faktor yang mempengaruhi prestasi timnas bola voli indoor supaya dapat bersaing dengan negara-negara Asia.

Salah satu evaluasi yang harus dilakukan adalah dengan melakukan analisis pertandingan pada setiap kejuaraan yang diselenggarakan baik di tingkat nasional maupun internasional. Karena dengan melakukan analisis pertandingan, dapat mengetahui berbagai hal seperti kondisi fisik atlet, teknik yang dilakukan pemain, apakah taktik dan strategi yang dipakai sudah tepat, bagaimana mental para atlet dalam menghadapi pertandingan dan lain-lain (Carling et al., 2006). Terdapat beberapa kejuaraan resmi bola voli yang diselenggarakan di Indonesia berdasarkan tingkatannya, yaitu: LIVOLI, KEJURNAS, Kejurda, Kejurkab dan PROLIGA. PROLIGA merupakan kompetisi vola boli yang diselenggarakan secara professional di bawah naungan PP PBVSI dan diselenggarakan secara rutin setiap tahunnya. PROLIGA juga merupakan kompetisi dalam bola voli yang bersifat Liga dengan lever tertinggi di Indonesia.

PROLIGA merupakan hasil terobosan Rita Subowo yang saat itu menjabat sebagai Ketua Umum PP. PBVSI, dan dilaksanakan pertama kali tahun 2002. Peraturan yang digunakan pada PROLIGA mengacu pada peraturan FIVB. Mulai dari sistem permainan, sistem pertandingan hingga alat dan kelengkapan dalam pertandingan sesuai standar yang telah ditetapkan oleh FIVB. Salah satu kelengkapan yang digunakan dalam event PROLIGA adalah adanya Volleyball Information System atau yang disebut dengan VIS. VIS merupakan sistem informasi yang dibangun untuk digunakan sebagai dukungan untuk penyelenggaraan kompetisi bola voli, serta dukungan untuk menginformasikan kepada masyarakat tentang bola voli. Sistem ini terdiri dari basis data pusat, semua data disimpan dalam satu set portal web dimana pengguna yang berwenang dapat memasukkan data ke dalam sistem dan data yang disimpan tersebut dapat dengan jelas disajikan kepada publik (Humski dan Skocir, 2011).

Analisis pertandingan merupakan faktor penting yang digunakan untuk mengevaluasi kinerja pribadi dan tim (Zetou et al., 2006). Analisis kinerja sangat penting untuk proses latihan olahraga karena memungkinkan interpretasi obyektif dari realitas kompleks dimana kinerja dan peningkatan kinerja terjadi (Fernandez-Echeverria et al., 2019). Kinerja dapat dinilai dari sejumlah perspektif yang berbeda seperti dari sisi biomekanik, fisiologis, psikologis, dll.

Sejalan dengan tren ini, sangat penting bahwa pelatih memiliki kemampuan untuk mengevaluasi kinerja atlet untuk mengidentifikasi kelemahan dan untuk memberikan umpan balik korektif teknis/taktis yang sesuai (Conejero, Claver, González-Silva, Fernández-Echeverría, \& Moreno, 2017). Hal ini memerlukan kemampuan pelatih untuk melakukan analisis pertandingan untuk mendapatkan berbagai informasi yang penting, dimana hasil dari analisis ini dapat digunakan untuk mendesain dan melakukan pengembangan program latihan (terkait fisik, teknik, taktik dan strategi serta mental), menganalisa kekuatan dan kelembahan tim lawan dan melakukan evaluasi permainan dan pertandingan secara keseluruhan.

Kemampuan untuk menganalisa adalah salah satu yang sulit untuk dilakukan oleh pelatih karena risiko subjektivitas dan keterbatasan ingatan manusia, menguntungkan bagi pelatih apabila memiliki akses ke alat yang akurat dan tepat untuk menganalisis pertandingan (George dan Panagiotis, 2008). Alat-alat seperti itu harus memberi pelatih data yang diperlukan untuk memfasilitasi pemahaman tentang permainan (Gesbert et al., 2016). Bola voli merupakan permainan memvoli bola di udara bolak-balik di atas net dengan menggunakan bagian tubuh mana saja asalkan sentuhan/pantulannya sempurna, dengan tujuan menjatuhkan bola dalam petak lapangan lawan (Muhajir, 2007: 113). Ahli 
lain berpendapat bahwa permainan bola voli pada hakikatnya adalah memvoli bola menggunakan seluruh anggota badan dan menyeberangkan melalui net ke lapangan lawan (Suhadi, 2004: 7).

Permainan bola voli dilakukan oleh dua regu yang saling berhadapan dengan jumlah tiap regu sebanyak 6 orang. Permainan dimulai dengan suatu pukulan yang dinamakan service. Dalam memvoli bola ke udara, masing-masing regu hanya boleh memainkan bola sebanyak 3 kali sentuhan atau pantulan di area lapangan sendiri dan setiap pemain boleh melakukan 2 kali sentuhan atau pantulan dengan catatan tidak dilakukan secara berturut-turut.

Lapangan permainan bola voli berbentuk persegi panjang dengan ukuran 18 x 9 meter, dikelilingi oleh daerah bebas dengan minimal di semua sisi $3 \mathrm{~m}$ (Susilo, 2015: 5). Lapangan bola voli dipisahkan oleh net dengan ukuran lebar 1 meter dan panjang 9,50 meter dipasang secara vertikal di atas garis tengah lapangan. Tinggi net untuk putra adalah 2,43 meter dan untuk putri 2,24 meter (PBVSI, 2017: 8). Pada setiap ujung atas tiang biasanya akan dipasang sebuah antena. Antena berfungsi sebagai pembatas gerakan bola yang menyamping atau melebar. Net yang memiliki lebar satu meter tersebut dipasang melebar di tengah lapangan (Brahma, 2008: 4).

Permainan bola voli dimainkan dengan tujuan memperoleh skor kemenangan sesuai dengan peraturan permainan yang berlaku. Kemenangan yang diperoleh mulai dari reli, set, game, babak, hingga menjadi juara merupakan rangkaian skor kemenangan yang dibangun mulai dari teknik individu hingga kemenangan tim (Apriyanto, 2015: 5). Kemenangan dalam pertandingan bola voli ditentukan dengan tim yang mampu mendapatkan 3 set terlebih dahulu dan mencapai poin 25. Pertandingan bola voli terdiri dari beberapa jumlah set sampai ada tim yang memenangkan 2 dari 3 atau 3 dari 4 set dalam satu pertandingan (https://www.volleyballyukon.com/volleyball-terms.html). Sehingga, dalam permainan bola voli dikenal dengan adanya durasi set dan durasi pertandingan. Durasi set (duration of a set) merupakan lamanya pertandingan dalam setiap setnya yang dihitung waktu bersih tanpa time out dan pergantian pemain di setiap set. Set merupakan rangkaian reli yang berakhir ketika satu tim mencetak 25 poin dengan margin minimum 2 poin atas lawannya. Jika pada set 1 sampai set 4 terjadi deuce (misal 24-24), maka permainan terus dilanjutkan hingga salah satu tim memimpin dengan 2 (dua) poin. Namun, untuk set kelima akan berakhir ketika salah satu tim mencetak 15 poin dengan selisih 2 (dua) poin minimum atas lawannya (misal: 15-13, atau 17-15, sampai tak terhingga).

Sedangkan durasi pertandingan bola voli merupakan lamanya waktu pertandingan atau sejumlah waktu yang terpakai untuk berbagai hal yang penggunaannya terkait dengan pertandingan tersebut (PBVSI, 2017: 14). Dapat disimpulkan bahwa durasi pertandingan (duration of a volleyball match) merupakan waktu dalam suatu pertandingan yang dimulai dari awal permainan bola voli dan diakhiri dengan kemenangan dari salah satu tim yang bertanding. Duration of a volleyball match dihitung berdasarkan waktu bersih selama pertandingan setelah dikurangi time out, pergantian pemain, dan jeda istirahat antar set (PBVSI, 2017: 14). Durasi pertandingan bola voli tidak tentu karena selesainya permainan bola voli ditentukan oleh perolehan rally point dan set yang dimainkan.

Penelitian-penelitian yang berkaitan dengan analisis hasil permainan bola voli berdasarkan pada spesifikasi permainan bola voli seperti durasi set dan durasi pertandingan sangat jarang. Apalagi analisis hasil permainan bola voli untuk tingkat nasional seperti PROLIGA. Berdasarkan dari penjabaran di atas, dan masih minimnya penelitian untuk menganalisis hasil permainan bola voli berdasarkan durasi pertandingan dan durasi set, maka dari itu peneliti tertarik untuk melakukan analisis terhadap durasi permainan bola voli pada PROLIGA 2019.

\section{METODE}

Metode penelitian yang digunakan pada penelitian ini adalah metode deskriptif dengan teknik survei. Adapun tujuan dari penelitian ini adalah untuk mengetahui: 1) Durasi set pada tim bola voli Proliga Tahun 2019 dan 2) Durasi pertandingan pada tim bola voli Proliga Tahun 2019. Tempat pengambilan data dilakukan di kantor PB. PBVSI Jakarta, waktu pengambilan data dilakukan pada bulan Oktober 2019 yaitu pada saat berlangsungnya pertandingan final four Proliga 2019. Populasi penelitian ini adalah peserta Proliga bolavoli 2019 sebanyak 6 tim putera dan 5 tim puteri. Namun, sampel yang digunakan pada penelitian ini hanya 4 tim putera dan 4 tim puteri. Teknik pengambilan sampel menggunakan purposive sampling, dengan kriteria yang digunakan adalah tim yang lolos pada babak putaran pertama dan putaran kedua pada final four Proliga bola voli 2019. 
Instrumen penelitian yang digunakan pada penelitian ini menggunakan data pada scoresheet hasil pertandingan resmi yang sudah ditanda tangani oleh kedua tim dan wasit. Data yang di ambil pada scoresheet merupakan data durasi set dan durasi pertandingan. Data durasi set ditunjukkan oleh waktu pertandingan bersih yang berjalan dalam satu set pertandingan. Durasi pertandingan ditunjukkan oleh total waktu pertandingan dari masing-masing tim, dimana waktu pertandingan akan selesai jika salah satu tim memenangkan pertandingan. Berikut adalah scoresheet yang digunakan untuk menghitung durasi set dan durasi pertandingan. Teknik analisis data yang digunakan pada penelitian ini adalah dengan melakukan redusi data dengan melakukan pemilihan dan penyederhanaan data mentah dari hasil pertandingan 4 tim putra dan puteri peserta final four Proliga bola voli 2019. Setelah di reduksi data hasil pertandingan, maka selanjutnya dilakukan penyajian data dalam bentuk tabel, grafik dan lain-lain. Dan terakhir dilakukan penarikan kesimpulan berdasarkan dari penyajian data yang telah dideskripsikan dalam bentuk kalimat yang singkat dan padat sehingga dapat memberikan makna pada data yang telah disajikan.

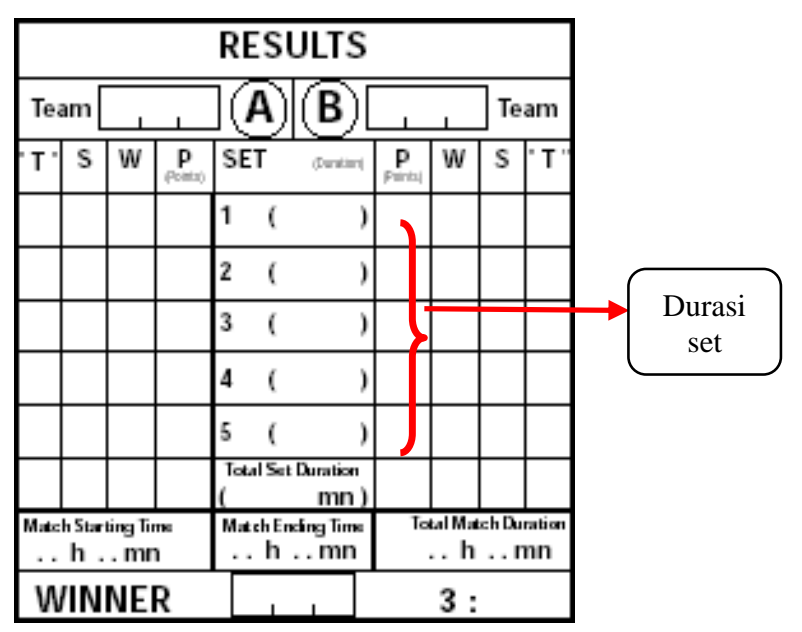

Gambar 1. Scoreshett Durasi Set

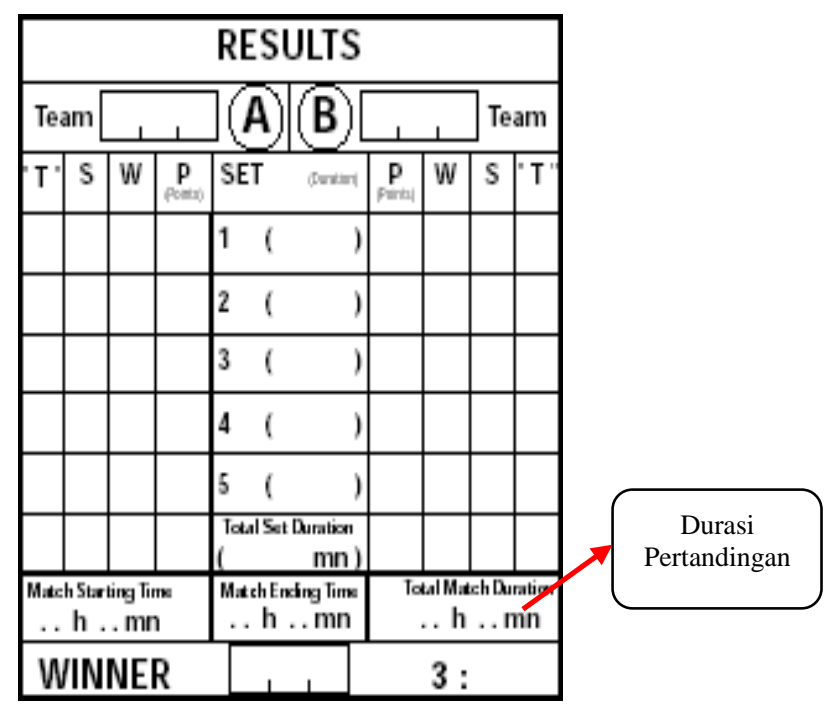

Gambar 2. Scorshett Durasi Pertandingan

\section{HASIL DAN PEMBAHASAN}

\section{Hasil}

Penelitian ini bertujuan untuk mengkaji tentang bagaimana durasi set dan durasi pertandingan dalam permainan bola voli pada PROLIGA 2019. Deskripsi data hasil penelitian mempunyai maksud untuk memberikan gambaran umum mengenai hasil pengolahan data yang didapat dari hasil pengamatan, yaitu durasi set dan durasi pertandingan dalam permainan bola voli pada PROLIGA 
2019. Data hasil penelitian diperoleh setelah dilakukan pengambilan data, kemudian dikumpulkan dan diolah melalui form penilaian yang dibuat oleh peneliti dan disetujui oleh ahli bola voli.

Data yang diperoleh pada penelitian ini merupakan data observasi pada atlet bola voli yang bermain di final four PROLIGA 2019 yang terdiri dari 4 (empat) tim putera dan tim puteri yang masuk babak final four PROLIGA 2019. Gambaran deskripsi data mencakup nilai terendah, nilai tertinggi, median, mean, modus dan simpangan baku dari waktu durasi set dan durasi pertandingan selama final four PROLIGA 2019 berlangsung. Adapun total keseluruhan match pada pertandingan final four PROLIGA 2019 adalah sebanyak 28 match. Berikut ini adalah data hasil penelitian dari data waktu durasi set dan durasi pertandingan pada match di pertandingan final four PROLIGA 2019.

\section{Durasi Pertandingan}

Hasil penelitian secara keseluruhan menyajikan data waktu durasi set dan durasi pertandingan secara keseluruhan match yang ada pada pertandingan final four PROLIGA 2019. Adapun total keseluruhan match pada pertandingan final four PROLIGA 2019 adalah sebanyak 28 match. Deskripsi data untuk durasi pertandingan secara keseluruhan adalah sebagai berikut: nilai terendah $=70$ menit, nilai tertinggi $=151$ menit, median $=106$, mean $=103.25$, modus $=82$ dan simpangan baku $=21.31$. Rincian tentang deskripsi data durasi pertandingan dan distribusi frekuensi untuk durasi pertandingan keseluruhan match pada pertandingan final four PROLIGA 2019 dapat dilihat pada tabel 1 dan 2 berikut ini.

Tabel 1. Deskripsi Data Durasi Pertandingan

\begin{tabular}{|c|c|}
\hline Deskripsi Data & Nilai \\
\hline Terendah & 70 \\
\hline Tertinggi & 151 \\
\hline Median & 106 \\
\hline Mean & 103.25 \\
\hline Modus & 82 \\
\hline Simpangan Baku & 21.31 \\
\hline
\end{tabular}

Tabel 2. Distribusi Frekuensi Durasi Pertandingan Keseluruhan Match PROLIGA 2019

\begin{tabular}{ccc}
\hline No & Interval & Frekuensi \\
\hline 1 & $70-83$ & 7 \\
2 & $84-97$ & 5 \\
3 & $98-111$ & 5 \\
4 & $112-125$ & 7 \\
5 & $126-139$ & 3 \\
6 & $140-153$ & 1 \\
\hline
\end{tabular}

Selanjutnya kecenderungan distribusi frekuensi durasi pertandingant keseluruhan match PROLIGA 2019 di atas digambarkan dalam grafik histogram sebagaimana tergambar pada gambar 1 di bawah ini.

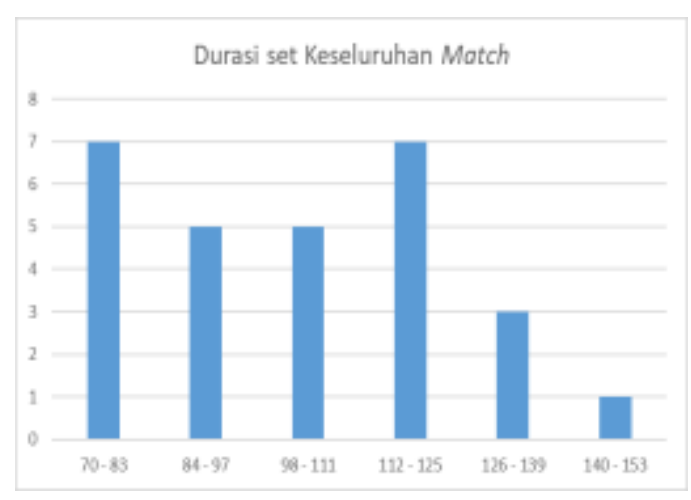

Gambar 1. Grafik Histogram Durasi Pertandingan Keseluruhan Match PROLIGA 2019 


\section{Durasi Set Secara Keseluruhan}

Deskripsi data keseluruhan durasi set secara keseluruhan menyajikan data waktu durasi set secara keseluruhan match yang ada pada pertandingan final four PROLIGA 2019. Data penelitian ini akan dijabarkan menurut set yang dimainkan, ada match yang berdurasi 3 set, 4 set dan 5 set. Dan data yang ditampilkan berikut ini berdasarkan total waktu setiap durasi set dari keseluruhan match PROLIGA 2019. Berikut adalah rangkuman deskripsi data untuk durasi set 1 hingga durasi set 5 .

Tabel 3. Deskripsi Data Untuk Durasi Set $1-$ Set 5

\begin{tabular}{|c|c|c|c|c|c|}
\hline \multirow{2}{*}{ Deskripsi Data } & \multicolumn{5}{|c|}{ Nilai } \\
\hline & Set 1 & Set 2 & Set 3 & Set 4 & Set 5 \\
\hline Terendah & 20 & 22 & 24 & 21 & 15 \\
\hline Tertinggi & 28 & 35 & 41 & 35 & 22 \\
\hline Median & 26.5 & 27 & 29 & 17.5 & 21 \\
\hline Mean & 26.4 & 28 & 30 & 27.8 & 19.8 \\
\hline Modus & 25 & 24 & 29 & 23 & 22 \\
\hline Simpangan Baku & 3.5 & 3.6 & 4 & 4.1 & 3.3 \\
\hline
\end{tabular}

\section{Durasi set 1}

Berikut ini adalah deskripsi data waktu durasi set 1 secara keseluruhan PROLIGA 2019. Adapun match yang memiliki durasi set 1 ini sebanyak 28 match. Deskripsi data untuk durasi set 1 secara keseluruhan adalah sebagai berikut: nilai terendah $=20$ menit, nilai tertinggi $=38$ menit, median $=26.5$, mean $=26.4$, modus $=25$ dan simpangan baku $=3.5$.

Berikut ini disajikan distribusi frekuensi untuk durasi set 1 secara keseluruhan match pada pertandingan PROLIGA 2019.

Tabel 4. Distribusi Frekuensi Durasi Set 1 Secara Keseluruhan Match PROLIGA 2019

\begin{tabular}{ccc}
\hline No & Nilai & Frekuensi \\
\hline 1 & $20-22$ & 3 \\
2 & $23-25$ & 9 \\
3 & $26-28$ & 11 \\
4 & $29-31$ & 4 \\
5 & $32-34$ & 0 \\
6 & $35-37$ & 0 \\
7 & $38-40$ & 1 \\
\hline
\end{tabular}

Selanjutnya kecenderungan distribusi frekuensi durasi set 1 secara keseluruhan match PROLIGA 2019 di atas digambarkan dalam grafik histogram sebagaimana tergambar pada gambar 2 . di bawah ini.

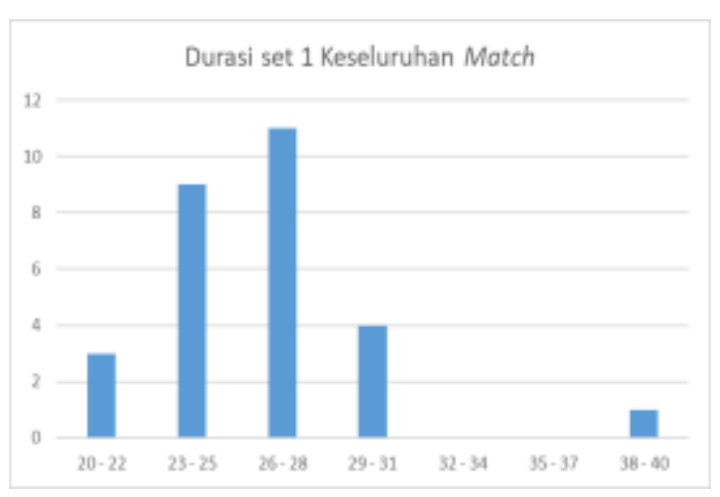

Gambar 2. Histogram Durasi Set 1 Secara Keseluruhan Match PROLIGA 2019

\section{Durasi Set 2}

Berikut ini adalah deskripsi data waktu durasi set 2 secara keseluruhan match PROLIGA 2019. Adapun match yang memiliki durasi set 2 ini sebanyak 28 match. Deskripsi data untuk durasi set 2 
secara keseluruhan adalah sebagai berikut: nilai terendah $=22$ menit, nilai tertinggi $=35$ menit, median $=27$, mean $=28$, modus $=24$ dan simpangan baku $=3.6$. Berikut ini disajikan distribusi frekuensi untuk durasi set 2 secara keseluruhan match pada pertandingan PROLIGA 2019.

Tabel 5. Distribusi Frekuensi Durasi Set 2 Secara Keseluruhan Match PROLIGA 2019

\begin{tabular}{ccc}
\hline No & Nilai & Frekuensi \\
\hline 1 & $22-23$ & 1 \\
2 & $24-25$ & 8 \\
3 & $26-27$ & 6 \\
4 & $28-29$ & 3 \\
5 & $30-31$ & 4 \\
6 & $32-33$ & 3 \\
7 & $34-35$ & 3 \\
\hline
\end{tabular}

Selanjutnya kecenderungan distribusi frekuensi durasi set 2 secara keseluruhan match final four Proliga 2019 di atas digambarkan dalam grafik histogram sebagaimana tergambar pada gambar 3. di bawah ini.

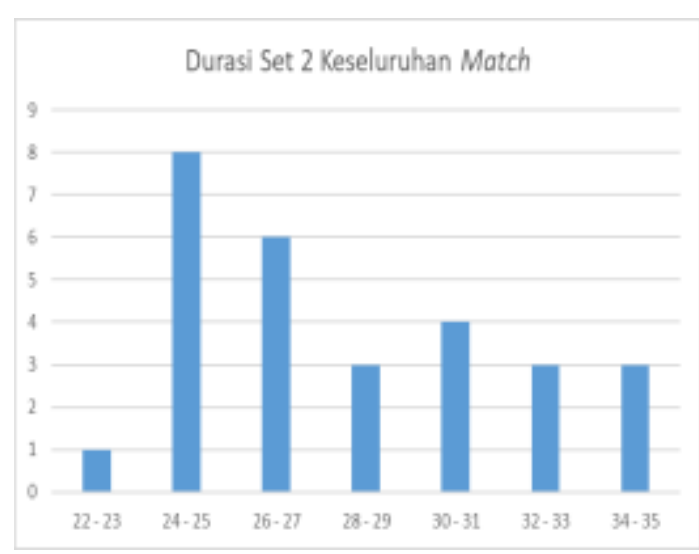

Gambar 3. Grafik Histogram Durasi Set 2 Secara Keseluruhan Match PROLIGA 2019.

\section{Durasi Set 3}

Berikut ini adalah deskripsi data waktu durasi set 3 secara keseluruhan match PROLIGA 2019. Adapun match yang memiliki durasi set 3 ini sebanyak 28 match. Deskripsi data untuk durasi set 3 secara keseluruhan adalah sebagai berikut: nilai terendah $=24$ menit, nilai tertinggi $=41$ menit, median $=29$, mean $=30$, modus $=29$ dan simpangan baku $=4$. Berikut ini disajikan distribusi frekuensi untuk durasi set 3 secara keseluruhan match pada pertandingan PROLIGA 2019.

Tabel 6. Distribusi Frekuensi Durasi Set 3 Secara Keseluruhan Match PROLIGA 2019

\begin{tabular}{ccc}
\hline No & Nilai & Frekuensi \\
\hline 1 & $24-26$ & 5 \\
2 & $27-29$ & 10 \\
3 & $30-32$ & 7 \\
4 & $33-35$ & 3 \\
5 & $36-38$ & 1 \\
6 & $39-41$ & 2 \\
\hline
\end{tabular}

Selanjutnya kecenderungan distribusi frekuensi durasi set 3 secara keseluruhan match PROLIGA 2019 di atas digambarkan dalam grafik histogram sebagaimana tergambar pada gambar 4. di bawah ini. 
Jurnal Keolahragaan 9 (1), 2021 - 93

Tirto Apriyanto, Ika Novitaria Marani, Tiara Putri Banyunimas

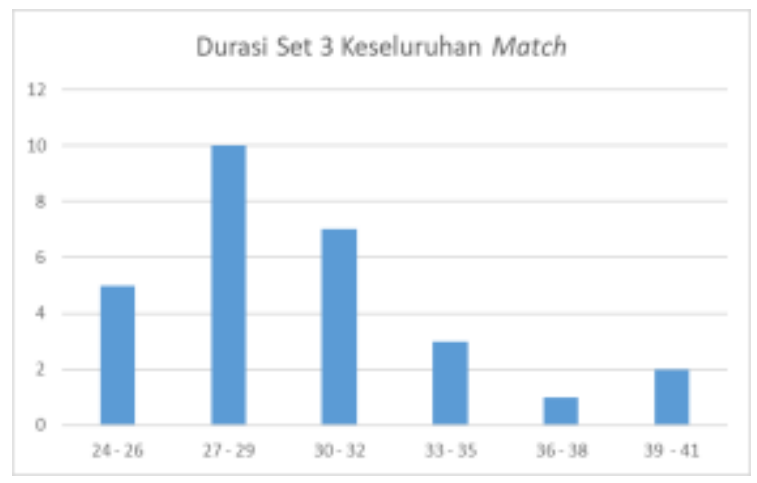

Gambar 4. Grafik Histogram Durasi Set 3 Secara Keseluruhan Match Final Four Proliga 2019

\section{Durasi Set 4}

Berikut ini adalah deskripsi data waktu durasi set 4 secara keseluruhan match final four PROLIGA 2019. Adapun match yang memiliki atau bermain hingga durasi set 4 ini sebanyak 16 match. Deskripsi data untuk durasi set 4 secara keseluruhan adalah sebagai berikut: nilai terendah $=21$ menit, nilai tertinggi $=35$ menit, median $=17.5$, mean $=27.8$, modus $=23$ dan simpangan baku $=4.1$. Berikut ini disajikan distribusi frekuensi untuk durasi set 4 secara keseluruhan match pada pertandingan final four Proliga bola voli 2019.

Tabel 7. Distribusi Frekuensi Durasi Set 4 Secara Keseluruhan Match Final Four Proliga 2019

\begin{tabular}{ccc}
\hline No & Nilai & Frekuensi \\
\hline 1 & $21-23$ & 3 \\
2 & $24-26$ & 3 \\
3 & $27-29$ & 5 \\
4 & $30-32$ & 2 \\
5 & $33-35$ & 3 \\
\hline \multicolumn{2}{c}{ Jumlah }
\end{tabular}

Selanjutnya kecenderungan distribusi frekuensi durasi set 4 secara keseluruhan match final four Proliga 2019 di atas digambarkan dalam grafik histogram sebagaimana tergambar pada gambar 5. di bawah ini.

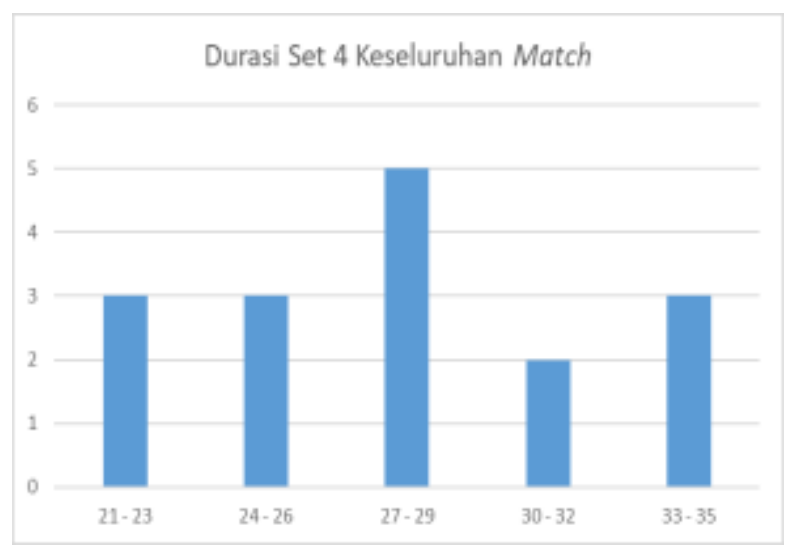

Gambar 5. Grafik Histogram Durasi Set 4 Secara Keseluruhan Match PROLIGA 2019.

\section{Durasi Set 5}

Berikut ini adalah deskripsi data waktu durasi set 5 secara keseluruhan match final four Proliga 2019. Adapun match yang memiliki atau bermain hingga durasi set 5 ini sebanyak 4 match. Deskripsi data untuk durasi set 5 secara keseluruhan adalah sebagai berikut: nilai terendah $=15$ menit, nilai tertinggi $=22$ menit, median $=21$, mean $=19.75$, modus $=22$ dan simpangan baku $=3.30$. Berikut ini disajikan distribusi frekuensi untuk durasi set 5 secara keseluruhan match pada pertandingan final four Proliga bola voli 2019. 
Jurnal Keolahragaan 9 (1), 2021 - 94

Tirto Apriyanto, Ika Novitaria Marani, Tiara Putri Banyunimas

Tabel 8. Distribusi Frekuensi Durasi Set 5 Secara Keseluruhan Match PROLIGA 2019

\begin{tabular}{ccc}
\hline No & Nilai & Frekuensi \\
\hline 1 & $15-16$ & 1 \\
2 & $17-18$ & 0 \\
3 & $19-20$ & 1 \\
4 & $21-22$ & 2 \\
\hline & Jumlah & 4 \\
\hline
\end{tabular}

Selanjutnya kecenderungan distribusi frekuensi durasi set 5 secara keseluruhan match PROLIGA 2019 di atas digambarkan dalam grafik histogram sebagaimana tergambar pada gambar 6 di bawah ini.

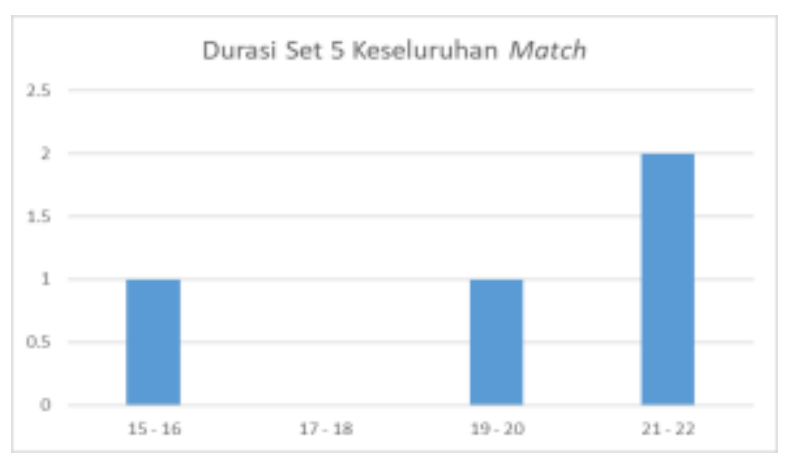

Gambar 6. Grafik Histogram Durasi Set 5 Secara Keseluruhan Match PROLIGA 2019.

\section{Pembahasan}

Penelitian ini merupakan penelitian deskriptif dengan tujuan untuk mengetahui spesifikasi permainan bola voli yang menganalisis data tentang durasi set dan durasi pertandingan pada pertandingan final four PROLIGA 2019. Data penelitian yang diambil merupakan data hasil pertandingan final four Proliga bola voli 2019 dengan keseluruhan match sebanyak 28 match. Pentingnya melakukan analisis pertandingan adalah untuk meningkatkan permainan. Secara khusus, informasi yang diperoleh dapat mengungkapkan aspek positif dari kinerja tim dan berfungsi untuk memperkuat tim, tetapi juga aspek negatif yang membutuhkan perhatian dan koreksi dalam latihan (Tenga dan Larsen, 2003). Karena Analisis pertandingan melibatkan pemilihan dan pengumpulan data pada aspek terpenting dari permainan untuk menilai kekuatan dan kelemahan tim dan pemain komponennya, sehingga berguna untuk mempersiapkan pertemuan di masa yang akan datang (Valladares et al., 2016).

Oleh karena itu, maka penelitian ini bertujuan untuk menganalisis permainan bola voli berdasarkan durasi set dan durasi pertandingan yang terjadi pada PROLIGA 2019. Durasi set merupakan lamanya pertandingan dalam setiap setnya yang dihitung waktu bersih tanpa time out dan pergantian pemain di setiap set. Pada pertandingan final four Proliga 2019 terdapat 28 pertandingan yang bermain sebanyak 3 set, ada 16 pertandingan yang bermain sebanyak 4 set dan ada 4 pertandingan yang bermain hingga 5 set. Dari 28 pertandingan yang bermain sebanyak 3 set, waktu durasi set yang tercepat adalah 20 menit dan yang terlama adalah 41 menit. Rata-rata waktu durasi set dari 3 set tersebut adalah 28.18 menit. Dan waktu durasi set yang paling banyak dicapai dalam 28 pertandingan adalah 25 menit sebanyak 11 pertandingan.

Waktu durasi set yang tercepat terjadi di set pertama, dan waku durasi set yang terlama terjadi di set ketiga. Sedangkan rata-rata waktu di set 1 adalah 26,43 menit, set kedua adalah 28.04 menit dan set ketiga adalah 30.07 menit. Sedangkan waktu durasi set di set pertama yang paling cepat adalah 20 menit dan waktu terlamanya adalah 38 menit. Waku durasi set di set kedua yang paling cepat adalah 22 menit dan waktu terlamanya adalah 35 menit. Dan waktu durasi set di set ketiga yang paling cepat adalah 24 menit dan yang terlama adalah 41 menit. Untuk durasi set pada match yang bermain hingga 4 set memiliki waktu tercepatnya adalah 21 menit dan waktu terlamanya adalah 35 menit. Dengan rata-rata waktu durasi setnya adalah 27.81 menit. Dan waktu yang paling sering terjadi adalah 23 menit, 27 menit dan 29 menit. Sedangkan untuk durasi set pada match yang bermain hingga 5 set memiliki waktu tercepatnya adalah 15 menit dan waktu terlamanya adalah 22 menit. Dengan rata-rata 
waktu durasi setnya adalah 19.75. Waktu yang paling sering terjadi adalah 22 menit sebanyak 2 pertandingan.

Hasil penelitian di atas menunjukkan bahwa pada set kedua terjadi penurunan waktu terlamanya apabila dibandingkan dengan waktu terlama set pertama yaitu sebanyak 3 menit. Namun, untuk waktu tercepatnya semua mengalami peningkatan sebanyak 2 menit di setiap setnya. Hal ini menunjukkan bahwa sangat penting bagi pelatih untuk memberikan perhatian terhadap rally yang terjadi di setiap setnya. Karena untuk memenangkan setiap set dalam pertandingan (match), sebuah tim harus bisa mendapatkan point 25 atau selisih 2 (dua) angka (Muhajir, 2007: 12). Ini merupakan peraturan permainan saat ini untuk bola voli yang menggunakan system rally point. Sehingga bisa dikatakan bahwa kemenangan yang diperoleh dalam 1 (satu) set permainan bola voli diperoleh mulai dari rally (Apriyanto, 2015: 5). Oleh karena itu, rally merupakan unit dasar yang penting untuk bisa mendapatkan point dalam permainan bola voli. Point dicetak dengan berbagai cara oleh pemain agar lawan yang melakukan kesalahan, "menerima bola", "pendaratan bola", dan lain-lain dalam satu rally (Kountouris, P. and Laios, 2000).

Reli merupakan serangkaian permainan di mana bola bolak-balik melintasi net beberapa kali sebelum skor dicetak (Monteleone, Deborah 2010: 16). Reli dianggap sebagai rangkaian sempurna bila terjadi rangkaian gerak permainan yang hasilnya adalah sebuah angka. Ini termasuk angka yang didapat dari penalti dan kehilangan service karena kesalahan service yang melebihi batas waktu. (PBVSI, 2017: 14). Perubahan waktu permainan dalam bola voli juga disebabkan oleh adanya perubahan scoring system, dari side out menjadi rally point. Perubahan yang terjadi tidak melibatkan modifikasi dalam karakteristik fisik dari rally, tetapi melibatkan pengurangan yang signifikan dalam jumlah aksi, melompat, dan memukul yang dilakukan oleh para pemain selama pertandingan (Giatsis, 2003). Dan apabila dikaitkan dengan teknik dan taktik, maka perubahan aturan melibatkan tentang pentingnya tindakan yang dilakukan pada saat fase ofensif rally yang pertama (José et al., 2015).

Berdasarkan penjelasan di atas, dapat dikatakan bahwa kemenangan suatu tim dalam satu set match ditentukan oleh rally yang dilakukan dalam bermain bola voli. Dalam bola voli, panjang rally dan waktu istirahat di antara rally cukup bervariasi selama pertandingan (José et al., 2012). Oleh karena itu, waktu kerja dan istirahat berfluktuasi secara acak tergantung pada saat pertandingan dan ini menandai adanya suatu intensitas usaha. Sehingga diharapkan para pelatih harus dapat mempertimbangkan tentang rasio kerja dan istirahat dalam permainan bola voli dalam membuat program latihan. Karena intensitas dan interval antara kerja dan istirahat pada saat latihan harus dibuat menyerupai intensitas dan interval dari kerja dan istirahat pada saat pertandingan (José M. Palao et al., 2015).

Perubahan terhadap waktu tidak hanya terjadi pada durasi set, tetapi juga pada durasi pertandingan. Durasi pertandingan adalah waktu pertandingan bersih yang dimenangkan oleh tim yang berhasil memenangkan tiga set permainan dengan skor 3-0 atau 3-1. Pada saat kondisi berada pada kedudukan 2-2, maka set ke-5 akan dimainkan hingga skor 15 atau hingga selisih minimal dua angka. Untuk penelitian ini, data durasi pertandingan diperoleh dari total waktu di mulainya hingga berakhirnya pertandingan yang dilakukan dalam 1 (satu) match. Pada pertandingan final four Proliga bola voli 2019 memiliki keseluruhan match sebanyak 28 match. Berdasarkan dari deskripsi data hasil penelitian di atas, dapat terlihat bahwa waktu durasi pertandingan yang paling cepat adalah 70 menit atau 1 jam 10 detik, dan waktu durasi pertandingan yang terlama adalah 151 menit atau 2 jam 31 menit. Waktu durasi pertandingan yang paling cepat dilakukan yaitu saat terjadi match antara Jakarta BNI 46 melawan Surabaya Bhayangkara Samator.

Durasi pertandingan pada match ini dapat terjadi dengan cepat karena pertandingan hanya berlangsung 3 set dengan skor 3-0. Sedangkan untuk waktu durasi pertandingan yang paling lama dilakukan yaitu saat terjadi match antara Jakarta Pertamina Energi melawan Jakarta PGN Popsivo Polwan. Waktu durasi pertandingan terjadi paling lama karena pada match ini berlangsung hingga 5 set dengan skor 2-3. Pertandingan ini terjadi dengan sangat ketat, yang dapat dilihat pada perolehan poin di setiap setnya. Sedangkan untuk rata-rata waktu durasi pertandingan yang terjadi pada pertandingan final four Proliga bola voli 2019 adalah 103 menit atau 1 jam 43 menit. Terdapat 5 (lima) match yang berada pada kisaran rata-rata waktu durasi pertandingan. Waktu durasi pertandingan yang paling sering terjadi dalam 28 pertandingan memiliki beberapa waktu, yaitu: 82 menit, 106 menit, 115 menit dan 138 menit. 
Berdasarkan hasil penelitian tersebut, menunjukkan bahwa durasi pertandingan bola voli berubah seiring waktu. Durasi pertandingan bola voli merupakan lamanya waktu pertandingan atau sejumlah waktu yang terpakai untuk berbagai hal yang penggunaannya terkait dengan pertandingan tersebut yang dihitung berdasarkan waktu bersih selama pertandingan setelah dikurangi time out, pergantian pemain dan jeda istirahat antar set (PBVSI, 2017: 14). Durasi pertandingan tergantung pada bagian-bagian yang ada dalam pertandingan tersebut, yaitu: sistem penilaian, panjang reli (waktu kerja permainan), waktu istirahat (waktu antara aksi unjuk rasa, pergantian, sanksi, time-out tim dan teknis, waktu antara set, cedera, dan lainnya), aspek teknis, dan tingkat pemain (Mladen Stankovic, 2019: 13).

Hasil penelitian juga menunjukkan bahwa durasi pertandingan yang terjadi pada PROLIGA 2019 rata-rata di atas 60 menit. Lamanya durasi pertandingan pada PROLIGA 2019 menunjukkan bahwa, durasi pertandingan dapat berlangsung lama jika level pemainnya berbeda. Hal ini dikarenakan adanya tahapan perkembangan pemain yang berbeda pada kategori usia. Yang tentunya hal ini berkaitan dengan proses kematangan dan pengembangan karakteristik antropometri dan fisik (Nikolaidis, et.al, 2015). Lamanya durasi pertandingan ini juga menunjukkan bahwa permainan bola voli merupakan olahraga dengan intensitas tinggi dan membutuhkan metabolisme anaerob yang disebabkan oleh reli yang bervariasi dan relatif panjang. Sehingga penting bagi pemain bola voli untuk dapat menghasilkan banyak energi dalam periode waktu yang sangat singkat (meledak-ledak) dan juga untuk memulihkan antara rally (dalam 15 detik) selama waktu habis (30-60 detik) dan di antara set (3 menit) (Vuorinen, 2018: 31).

Beradsarkan pada penjelasan di atas, maka terlihat bahwa jumlah waktu untuk bermain dan waktu istirahat selama pertandingan dalam bola voli (antara bola mati sampai servis, time out, istirahat antar set) satu berbanding tiga. Dengan demikian energi akan tercukupi oleh sistem fosfagen. Waktu antara bola mati sampai servis, time out, istirahat antar set panjangnya tiga kali waktu rally, sehingga jika dimanfaatkan dengan baik sistem fosfagen akan sudah pulih kembali, tanpa terjadi akumulasi laktat yang berarti (Pranatahadi, 2008: 15). Oleh karena itu atlet bola voli harus mampu menghasilkan energi yang cepat dan juga harus mampu memulihkan energi dengan secepat mungkin dalam mengantisipasi waktu berikutnya.

Dalam bermain bola voli, atlet menghasilkan energi untuk kontraksi otot yang kuat terutama melalui sistem ATP-CP dan glikolisis anaerobik. Olahraga bola voli menggunakan sistem energi anaerobik yang berasal dari ATP-PC sebesar $70 \%$. Sistem ATP-CP hanya mampu menyediakan energi untuk aktivitas kurang dari 30 detik (Supriatna, 2016). Pada permainan bola voli, sistem energi ATP-CP dapat dilihat hampir pada semua aktivitas seperti Smash yang dilakukan dengan frekuensi yang tinggi, itensitas yang sangat tinggi dan setiap gerakan dilakukan dengan kecepatan yang tinggi pula dalam waktu yang sangat singkat.

Durasi pertandingan juga mempengaruhi komponen fisik yang diperlukan dalam bermain bola voli. Adapun kondisi fisik yang diperlukan dalam permainan bola voli, sesuai dengan karakteristik dari gerak yang terkandung di dalam permainan yaitu power, take-off power, reactive power, dan power endurance (Reeser, Jonathan, 2003:29). Karena permainan bola voli merupakan olahraga eksplosif serta memerlukan kecepatan yang tinggi. Setiap atlet harus melakukan lompatan maksimal yang berulang-ulang serta harus mampu mengubah arah gerak dalam kecepatan yang sangat tinggi.

Atlet perlu mengembangkan kekuatan pada tingkatan yang tinggi (Willardson, 2014:179). Biomotor yang sangat penting untuk cabang bola voli yaitu muscular strength dan anaerobic power. muscular endurance, cardiorespiratory endurance, flexibility dan body composition yaitu penting, sedangkan anaerobic capacity tidak penting (Russel R Pate, 2013:283).

Oleh karena itu, sangatlah penting bagi pelatih untuk memberikan perhatian pada spesifikasi permainan bola voli seperti durasi set dan durasi pertandingan kemudian dilakukan analisis selama kompetisi. Analisis pertandingan terdiri dari rekaman objektif dan pemeriksaan terperinci dari setiap aksi pertandingan selama kompetisi (Ferrari et al., 2019). Karena informasi yang diekstrak dari analisis pertandingan mempengaruhi gaya dan taktik. Dalam banyak situasi, serangkaian analisis pertandingan yang diperoleh terkait dengan taktik dan strategi yang dikenal dengan ofensif dan defensif. Berdasarkan dari hasil-hasil penelitian menunjukkan bahwa keberhasilan permainan sebuah tim ada pada saat tim melakukan ofensif. Hasil penelitian tersebut menunjukkan bahwa kinerja dalam serangan sangat terkait dengan keberhasilan dalam bola voli (Marcelino et al., 2011). Hal ini disebabkan karena setiap tim memiliki kesempatan untuk mencetak poin dengan melayani, memblokir atau menyerang dan dari kesalahan lawan (Häyrinen dan Tampouratzis, 2012). Hasil analisis yang 
ditetapkan dapat membantu pelatih merancang persiapan fisik yang tepat, menentukan strategi pertahanan yang memadai dan jenis serangan terbaik, menghindari kesalahan umum, meningkatkan efektivitas tim secara keseluruhan dan mengembangkan sistem latihan.

Durasi pertandingan bola voli telah berubah seiring waktu. Perubahan ini terjadi karena adanya perubahan pada sistem penilaian (scoring system) dari sistem side out menjadi sistem rally point. Perubahan scoring system memberikan pengaruh terhadap pengurangan durasi pertandingan menjadi lebih pendek dan lebih stabil (Giatsis, 2003). Hal ini dikarenakan pada sistem side out digunakan, poin hanya bisa dicetak oleh tim yang melayani bola. Jika tim yang tidak melayani bola memenangkan reli, mereka tidak akan diberikan poin sebagai pengakuan atas hal itu. Sebaliknya, mereka akan mendapatkan bola untuk melayani diri sendiri, pada titik mana mereka bisa skor poin jika mereka memenangkan reli. Point pada sistem side out yang harus didapatkan oleh sebuah tim untuk memenangkan 1 (satu) set adalah 15.

Sedangkan pada saat sistem rally point digunakan Satu poin dicetak setiap kali bola menyentuh lapangan dalam batas atau kapan pun kesalahan dibuat. Tim yang tidak membuat kesalahan atau membiarkan bola untuk memukul di sisi mereka dari lantai diberikan satu poin terlepas dari apakah mereka melayani bola. Tim yang memenangkan poin kemudian berfungsi untuk poin berikutnya. Dan point pada sistem rally point yang harus didapatkan oleh sebuah tim untuk memperoleh kemenangan adalah 25 setiap 1 (satu) set.

Perubahan scoring system juga memberikan pengaruh terhadap durasi pertandingan dan jumlah rally yang dimainkan (Giatsis, 2003). Pengaruh ini memberikan informasi tentang karakteristik pertandingan yang dimainkan oleh kedua tim. Mengetahui informasi tentang karakteristik pertandingan adalah penting sebagai langkah pertama untuk merancang sesi latihan dan untuk memahami efek dari perubahan peraturan. Panjang pertandingan tergantung pada bagian-bagian yang terjadi selama pertandingan, yaitu: sistem penilaian, panjang reli (waktu kerja permainan), waktu istirahat (waktu antara aksi unjuk rasa, pergantian, sanksi, time-out tim dan teknis, waktu antara set, cedera, dan lainnya) aspek teknis) dan tingkat pemain. (Mladen Stankovic, 2019: 13).

Berdasarkan hasil penelitian tersebut, menunjukkan bahwa durasi pertandingan bola voli berubah seiring berjalannya waktu. Durasi pertandingan tergantung pada bagian-bagian yang ada dalam pertandingan tersebut, yaitu: sistem penilaian, panjang reli (waktu kerja permainan), waktu istirahat (waktu antara aksi unjuk rasa, pergantian, sanksi, time-out tim dan teknis, waktu antara set, cedera, dan lainnya) aspek teknis) dan tingkat pemain). Durasi pertandingan pada final four Proliga 2019 menunjukkan bahwa durasi pertandingan di atas 60 menit. Hal ini menunjukkan bahwa atlet voli memerlukan sistem energi ATP-CP dan glikolisis anaerobic untuk bisa menghasilkan energy untuk kontraksi otot yang kuat. Sehingga, pelatih ahrus membuat program latihan yang dirancang untuk meningkatkan sistem energi ATP-CP dan glikolisis anaerobic. Pada permainan bolvoli, sistem energi ATP-CP dapat dilihat hampir pada semua aktivitas seperti: smash, block, jump servce.

Semua aktivitas pada permainan olahraga secara dominan dilakukan dengan frekuensi yang tinggi, intensitas yang sangat tinggi, dan setiap gerakan dilakukan dengan kecepatan yang tinggi pula dalam waktu yang sangat singkat. Pada permainan bolavoli, setelah cadangan ATP-CP habis dan tidak tersedia oksigen yang cukup, pembentukan ATP masih dapat dilakukan dengan cara pemecahan glikogen, yang sering disebut glikolisis anaerobik. Sistem ini menyediakan ATP dari pemecahan glukosa atau glikogen secara anaerobik.

Hasil penelitian juga menunjukkan bahwa durasi pertandingan mempengaruhi komponen fisik yang diperlukan dalam permainan bola voli. Kondisi fisik yang diperlukan dalam permainan bola voli sesuai dengan karakteristik dari gerak yang terkandung di dalam permainan yaitu power, take-off power, reactive power, dan power endurance. Komponen fisik ini dibutuhkan mengingat aturan permainan bola voli menggunakan sistem rally point sehingga memaksa para atlet untuk bermain dengan tempo yang cepat dan menggunakan serangan smash yang dilakukan berulang-ulang dengan intensitas tinggi. Atlet tetap memiliki waktu istirahat untuk memulihkan tubuh diantara serangan. Permainan bola voli merupakan olahraga eksplosif yang memerlukan kecepatan tinggi, karena setiap atlet melakukan lompatan maksimal yang berulang-ulang serta harus mampu mengubah arah gerak dalam kecepatan yang tinggi. 
Jurnal Keolahragaan 9 (1), 2021 - 98

Tirto Apriyanto, Ika Novitaria Marani, Tiara Putri Banyunimas

\section{SIMPULAN}

Berdasarkan dari deskripsi data dan pembahasan hasil penelitian, maka dapat ditarik kesimpulan dari penelitian ini adalah durasi pertandingan pada pertandingan final four Proliga 2019 yang paling cepat adalah 70 menit atau 1 jam 10 detik, dan waktu durasi pertandingan yang terlama adalah 151 menit atau 2 jam 31 menit. Durasi set pada pertandingan final four Proliga 2019 yang paling cepat adalah 20 menit dan terjadi di durasi set 1 . Sedangkan waktu durasi set terlama adalah 41 menit dan terjadi di durasi set 3. Berdasarkan dari hasil penelitian tersebut, peneliti memberikan saran kepada para pelatih untuk selalu memiliki catatan tentang durasi set dan durasi pertandingan setiap tim yang bertanding agar pelatih dapat menyusun taktik dan strategi yang tepat apabila kedua tim saling bertemu kembali. Selain itu, pelatih diharapkan mempunyai rekam jejak catatan tentang durasi set dan durasi pertandingan pada setiap pertandingan, agar pelatih dapat menyusun program latihan yang tepat untuk meningkatkan komponen fisik yang dibutuhkan oleh atlet di tim.

\section{DAFTAR PUSTAKA}

Apriyanto, T. (2015). Buku Ajar Teknik Permainan Bola Voli. Jakarta: FIK UNJ.

Brahma. (2008). Teknik Dasar Bolavoli.

C.Reeser, Jonathan; Bahr, R. (2003). Volleyball: Handbook of Sports Medicine and Science. Oxford: Blackwell Science Ltd.

Carling, E. C., Williams, A. M., \& Reilly, T. (2006). Book review Handbook Of Soccer Match Analysis : A Systematic Approach To Improving Performance (C) 2006 . This work is published under http://creativecommons.org/licenses/by-nc-nd/4.0/ ( the "License"). Notwithstanding the ProQuest Terms and Conditions , .

Conejero, M., Claver, F., González-Silva, J., Fernández-Echeverría, C., \& Moreno, P. (2017). Analysis of performance in game actions in volleyball, according to the classification. Revista Portuguesa de Ciências Do Desporto, 2017(S1A), 196-204. https://doi.org/10.5628/rpcd.17.s1a.196

Fernandez-Echeverria, C., Mesquita, I., Conejero, M., \& Moreno, M. P. (2019). Perceptions of elite volleyball players on the importance of match analysis during the training process. International Journal of Performance Analysis in Sport, 19(1), 49-64. https://doi.org/10.1080/24748668.2018.1559544

Ferrari, W. R., Sarmento, H., \& Vaz, V. (2019). Match analysis in handball: A systematic review. Montenegrin Journal of Sports Science and Medicine, 8(2), 63-76. https://doi.org/10.26773/mjssm.190909

George, G., \& Panagiotis, Z. (2008). Statistical Analysis of Men's FIVB Beach Volleyball Team Performance. International Journal of Performance Analysis in Sport, 8(1), 31-43. https://doi.org/10.1080/24748668.2008.11868420

Gesbert, V., Carrel, J., Philippe, R. A., \& Hauw, D. (2016). Elite volleyball coaches' experience using a statistical information system. International Journal of Performance Analysis in Sport, 16(2), 612-632. https://doi.org/10.1080/24748668.2016.11868913

Giatsis, G. (2003). The effect of changing the rules on score fluctuation and match duration in the FIVB women's beach volleyball. International Journal of Performance Analysis in Sport, 3(1), 57-64. https://doi.org/10.1080/24748668.2003.11868275

Häyrinen, M., \& Tampouratzis, K. (2012). Technical and tactical game analysis of elite female beach volleyball.

Humski, L., \& Skocir, Z. (2011). Volleyball information system. Proceedings of the 11th International Conference on Telecommunications, ConTEL 2011.

Kountouris, P. and Laios, Y. (2000). Changes affecting the game of Volleyball by the enforcement of the new regulations. Coaching Volleyball, 3(1), 25-30.

https://doi.org/10.1080/24748668.2003.11868275 
Marcelino, R., Mesquita, I., \& Sampaio, J. (2011). Effects of quality of opposition and match status on technical and tactical performances in elite volleyball. Journal of Sports Sciences, 29(7), 733741. https://doi.org/10.1080/02640414.2011.552516

Mladen Stankovic, Guillermo Ruiz-Llamas, Dušan Perić, M. E. Q.-E. (2019). Point-scoring plays related to level of set win and in-game role during volleyball rules testing. JOURNAL OF HUMAN SPORT \& EXERCISE, 14(1), 86-98. https://doi.org/10.14198/jhse.2019.141.07

Monteleone, D. W. C. dan J. J. (2010). Winning Volleyball For Girls third edition. New York: Chelsea House Publishers.

Muhajir. (2007). Pendidikan Jasmani Olahraga dan Kesehatan. Jakarta: PT. Ghalia Indonesia Printing.

Nindy. (2017). Tim Voli Putri Persembahkan Medali Perak untuk Kontingen Indonesia.

Palao, José M., López-Martínez, A. B., Valadés, D., \& Ortega, E. (2015). Physical actions and workrest time in women's beach volleyball. International Journal of Performance Analysis in Sport, 15(1), 424-429. https://doi.org/10.1080/24748668.2015.11868803

Palao, José Manuel, Valades, D., \& Ortega, E. (2012). Match duration and number of rallies in men's and women's 2000-2010 FIVB world tour beach volleyball. Journal of Human Kinetics, 34(1), 99-104. https://doi.org/10.2478/v10078-012-0068-7

PBVSI. (2017). Peraturan Resmi Bolavoli 2017-2020. Jakarta: PBVSI.

Pranatahadi. (2008). Kapasitas Anaerobik Tidak Penting Untuk Pemain Bolavoli. Olahraga, 14, 1.

Russel R Pate, B. M. C. dan R. R. (2013). Dasar-Dasar Ilmu Kepelatihan, Terjemahan Kasiyo Dwijowinoto. Semarang: IKIP Press.

Suhadi. (2004). Pengaruh Pembelajaran Bola Voli. Yogyakarta: FIK UNY Yogyakarta.

Supriatna, E. (2016). Sistem Energi dalam Permainan Bola Voli. Performa Olahraga, II(2), 121.

Susilo. (2015). Buku Ajar "Permainan Bola Voli Lanjutan. Jakarta: FIK UNJ.

Tenga, A., \& Larsen, Ø. (2003). Testing the Validity of Match Analysis to describe Playing Styles in Football. International Journal of Performance Analysis in Sport, 3(2), 90-102. https://doi.org/10.1080/24748668.2003.11868280

Valladares, N., García-Tormo, J. V., \& João, P. V. (2016). Analysis of variables affecting performance in senior female volleyball world championship 2014. International Journal of Performance Analysis in Sport, 16(1), 401-411. https://doi.org/10.1080/24748668.2016.11868895

Vuorinen, K. (2018). Modern Volleyball Analysis and Training Periodization. Sport Coaching and Fitness, 028.

Willardson, J. M. (Ed.). (2014). Developing The Core. U.S: Human Kinetics.

Zetou, E., Tsigilis, N., Moustakidis, A., \& Komninakidou, A. (2006). Playing characteristics of men's Olympic Volleyball teams in complex II. International Journal of Performance Analysis in Sport, 6(1), 172-177. https://doi.org/10.1080/24748668.2006.11868365 